\title{
Caddo Ceramic Vessels from the McSpadden Site
}

Robert Z. Selden Jr. Heritage Research Center, Stephen F. Austin State University

Follow this and additional works at: https://scholarworks.sfasu.edu/ita

Part of the American Material Culture Commons, Archaeological Anthropology Commons, Environmental Studies Commons, Other American Studies Commons, Other Arts and Humanities Commons, Other History of Art, Architecture, and Archaeology Commons, and the United States History Commons

Tell us how this article helped you.

This Article is brought to you for free and open access by the Center for Regional Heritage Research at SFA ScholarWorks. It has been accepted for inclusion in Index of Texas Archaeology: Open Access Gray Literature from the Lone Star State by an authorized editor of SFA ScholarWorks. For more information, please contact cdsscholarworks@sfasu.edu. 


\section{Caddo Ceramic Vessels from the McSpadden Site}

Creative Commons License

(c) $)$ (i) @

This work is licensed under a Creative Commons Attribution-NonCommercial 4.0 International License 


\section{Caddo Ceramic Vessels from the McSpadden Site}

\section{Robert Z. Selden, Jr.}

\section{INTRODUCTION}

The McSpadden site (unrecorded and with no site trinomial) is located on the outskirts of Frankston, Texas, in Anderson County, where three Caddo vessels were recovered during the construction of a local roadway during the early 1950s (Figure 1). These vessels are currently curated in a private collection in College Station, Texas. All come from the same small area, and based upon their stylistic character and vessel forms, appear to date to the Late Caddo period (ca. A.D. 1400-1650) in this part of East Texas (see Kleinschmidt 1982; Story 1995; Perttula et al. 2011).

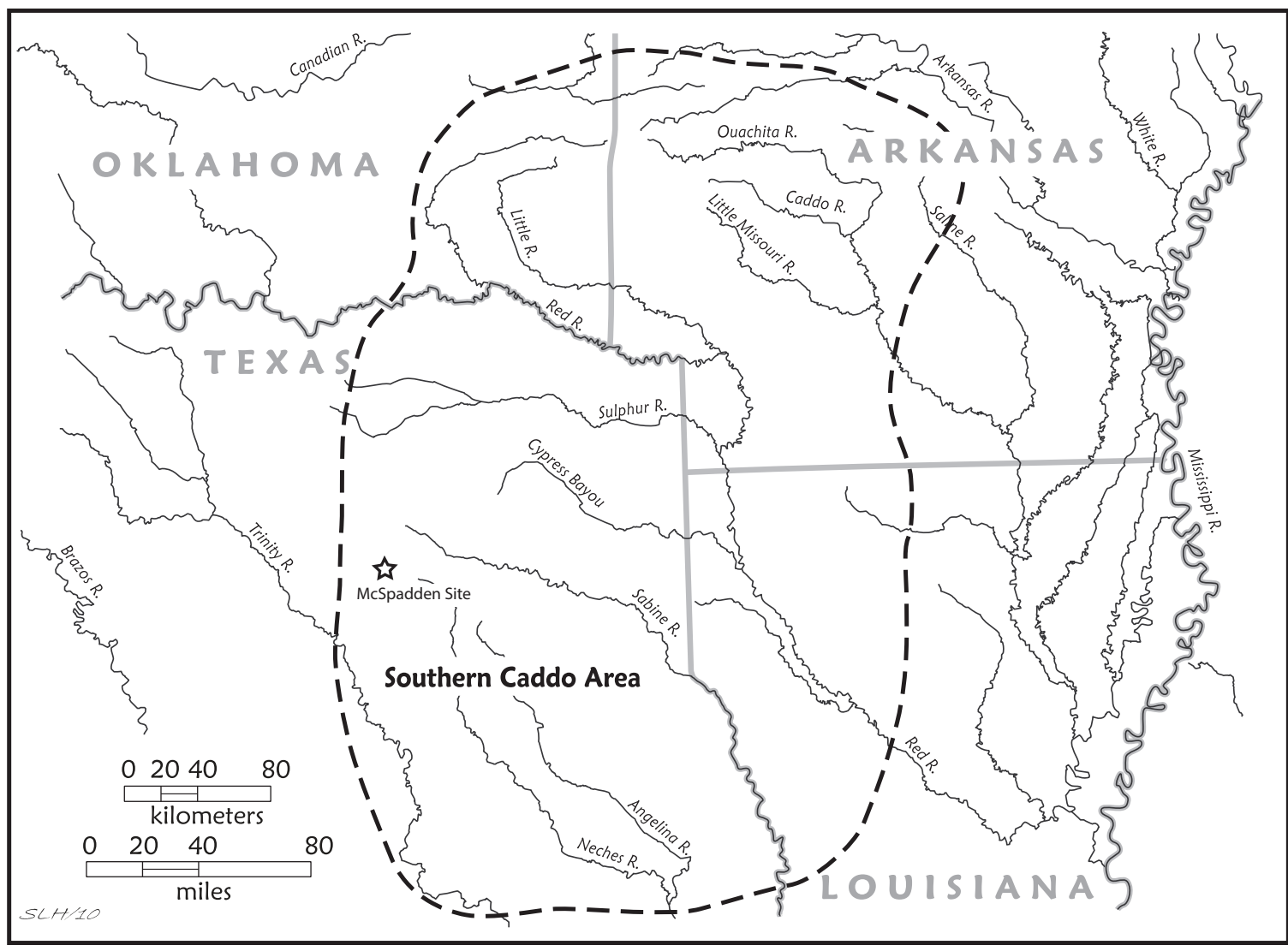

Figure 1. Location of the McSpadden site in the southern Caddo area. 


\section{VESSEL DOCUMENTATION}

SITE NAME OR SITE NUMBER: McSpadden

VESSEL FORM: Jar

NON-PLASTICS AND PASTE: grog

RIM AND LIP FORM: direct rim, rounded lip; appliqued nodes/handles

CORE COLOR: A (fired and cooled in an oxidizing environment)

INTERIOR SURFACE COLOR: Dark brown; fire clouding on base, body, and the rim

EXTERIOR SURFACE COLOR: Reddish-brown; fire clouding on base

WALL THICKNESS (IN MM): 5.7 (rim)

INTERIOR SURFACE TREATMENT: Smoothed

EXTERIOR SURFACE TREATMENT: Smoothed

HEIGHT (IN CM): 18.2

ORIFICE DIAMETER (IN CM): 15.2

DIAMETER AT BOTTOM OF RIM OR NECK (IN CM): 14.5

BASE DIAMETER (IN CM) AND SHAPE OF

BASE: 8.4; circular, flat

ESTIMATED VOLUME (IN LITERS): 2.5

DECORATION (INCLUDING MOTIF AND ELEMENTS WHEN APPARENT): Brushed and appliqued (Figure 2a-b); there are diagonal brushing marks on the rim, surrounding the appliqued handles.

PIGMENT USE AND LOCATION ON VESSEL: none

TYPE AND VARIETY (IF KNOWN): Unidentified utility ware

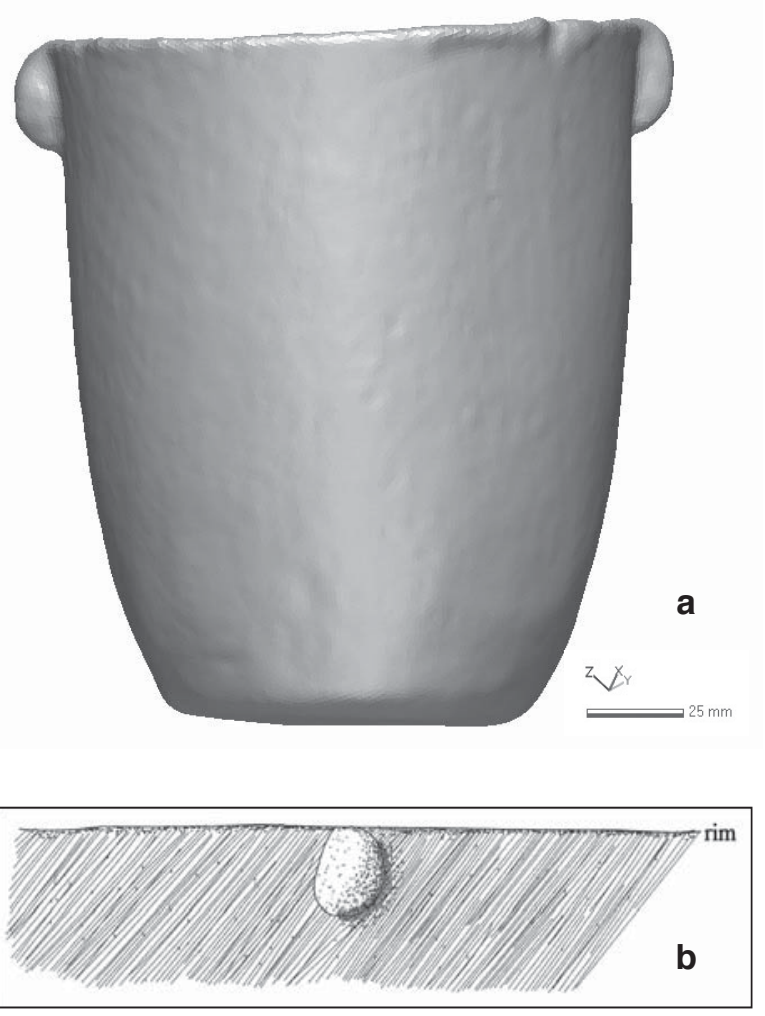

Figure 2. Jar with appliqued nodes/handles from the McSpadden site: a, 3-D scan; b, decorative elements. 
SITE NAME OR SITE NUMBER: McSpadden

VESSEL FORM: Jar

NON-PLASTICS AND PASTE: grog-bone

RIM AND LIP FORM: everted rim, rounded lip; strap handles

CORE COLOR: F (fired in a reducing environment and cooled in the open air)

INTERIOR SURFACE COLOR: Brown; fire clouding on base and rim

EXTERIOR SURFACE COLOR: Brown; fire clouding on body and rim

WALL THICKNESS (IN MM): 5.6 (rim)

INTERIOR SURFACE TREATMENT: Smoothed

EXTERIOR SURFACE TREATMENT: Burnished

HEIGHT (IN CM): 12.4

ORIFICE DIAMETER (IN CM): 10.7

DIAMETER AT BOTTOM OF RIM OR NECK (IN CM): 9.8

BASE DIAMETER (IN CM) AND SHAPE OF

BASE: 8.3; circular, flat

ESTIMATED VOLUME (IN LITERS): 0.8

DECORATION (INCLUDING MOTIF AND ELEMENTS WHEN APPARENT): Engraved/pinched elements (Figure 3a-b). The rim has six crosshatched brackets, creating oval panel areas on either side of the appliqued strap handles. On the vessel body are four vertical rows of pinched ridges; two of the vertical pinched rows are underneath the strap handles.
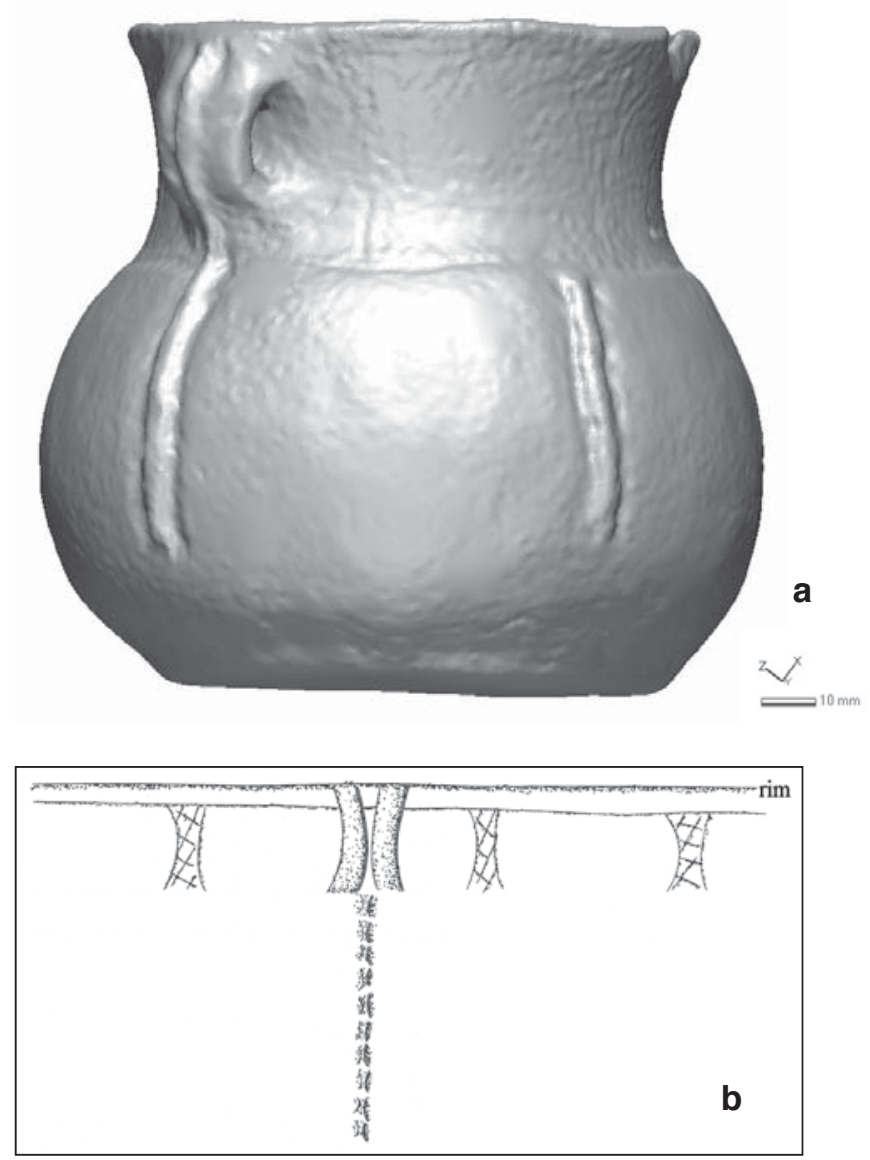

Figure 3. Jar with strap handles recovered from the McSpadden site: a, 3-D scan; b, decorative elements.

PIGMENT USE AND LOCATION ON VESSEL: Red; in engraved lines

TYPE AND VARIETY (IF KNOWN): cf. Poynor Engraved, var. Hood 
SITE NAME OR SITE NUMBER: McSpadden

VESSEL FORM: Carinated Bowl

NON-PLASTICS AND PASTE: grog

RIM AND LIP FORM: direct rim, rounded lip

CORE COLOR: B (fired and cooled in a reducing environment)

INTERIOR SURFACE COLOR: Brown; fire clouding on base and rim

EXTERIOR SURFACE COLOR: Brown; fire clouding on base, body and rim

WALL THICKNESS (IN MM): 6.7 (rim)

INTERIOR SURFACE TREATMENT:

Smoothed

EXTERIOR SURFACE TREATMENT:

Smoothed

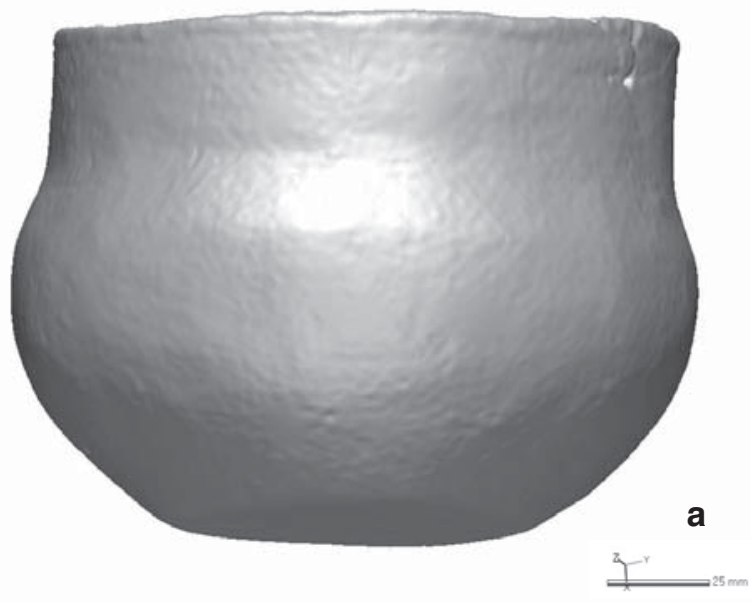

HEIGHT (IN CM): 12.1

ORIFICE DIAMETER (IN CM): 15.1

DIAMETER AT BOTTOM OF RIM OR

NECK (IN CM): 17.2

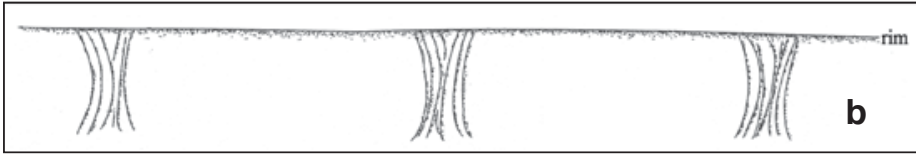

BASE DIAMETER (IN CM) AND

SHAPE OF BASE: 9.2; circular, flat

Figure 4. Carinated bowl recovered from the McSpadden site: a, 3-D scan; b, decorative elements.

ESTIMATED VOLUME (IN LITERS): 1.1

DECORATION (INCLUDING MOTIF AND ELEMENTS WHEN APPARENT): Engraved elements (Figure 4a-b). The rim has 10 panels formed by hatched engraved brackets that encircle the vessel.

PIGMENT USE AND LOCATION ON VESSEL: Red; in engraved lines

TYPE AND VARIETY (IF KNOWN): Poynor Engraved, var. Hood (see Perttula et al. 2011; Suhm and Jelks 1962:122-123). 


\section{SUMMARY AND CONCLUSIONS}

These three vessels, currently in a private collection in College Station, Texas, were likely recovered from burial contexts. The decorative motifs on the vessels suggest that they were manufactured by Caddo peoples during the Late Caddo period (ca. A.D. 1400-1650), and they are consistent with upper Neches River basin ceramic types from the Frankston phase. The occurrence of Poynor Engraved, var. Hood vessels from the McSpadden site further suggests that it was occupied by Caddo peoples primarily between ca. A.D. 1480-1650 (Perttula et al. 2011:Table 6-37).

\section{ACKNOWLEDGEMENTS}

I would like to thank Mr. Sonny McSpadden for allowing access and permission to document his collection.

\section{REFERENCES CITED}

Kleinschmidt, U. K. W.

1982 Review and Analysis of the A. C. Saunders Site, 41AN19, Anderson County, Texas. Master's thesis, Department of Anthropology, The University of Texas at Austin.

Perttula, T. K., D. B. Kelley, and R. A. Ricklis (assemblers and editors)

2011 Archeological Investigations at the Lang Pasture Site (41AN38) in the Upper Neches River Basin of East Texas. Report No. 129. Texas Department of Transportation, Archeological Studies Program, Environmental Affairs Division, Austin.

Story, D. A. (editor)

1995 The Deshazo Site, Nacogdoches County, Texas, Vol. 2: Artifacts of Native Manufacture. Studies in Archeology 21. Texas Archeological Research Laboratory, The University of Texas at Austin.

Suhm, D. A., and E. B. Jelks (editors)

1962 Handbook of Texas Archeology: Type Descriptions. Special Publication No. 1, Texas Archeological Society, and Bulletin No. 4, Texas Memorial Museum, Austin. Reprinted in 2009, Gustav's Library, Davenport, Iowa. 